\title{
ELEOLITE-SYENITE OF LITCHFIELD, MAINE, AND HAWES' HORNBLENDE-SYENITE FROM RED HILL, NEW HAMP- SHIRE.
}

\author{
BY W. S. BAYLEY.
}

(Read before the Society December \$1, 1891.)

CONTENTS.

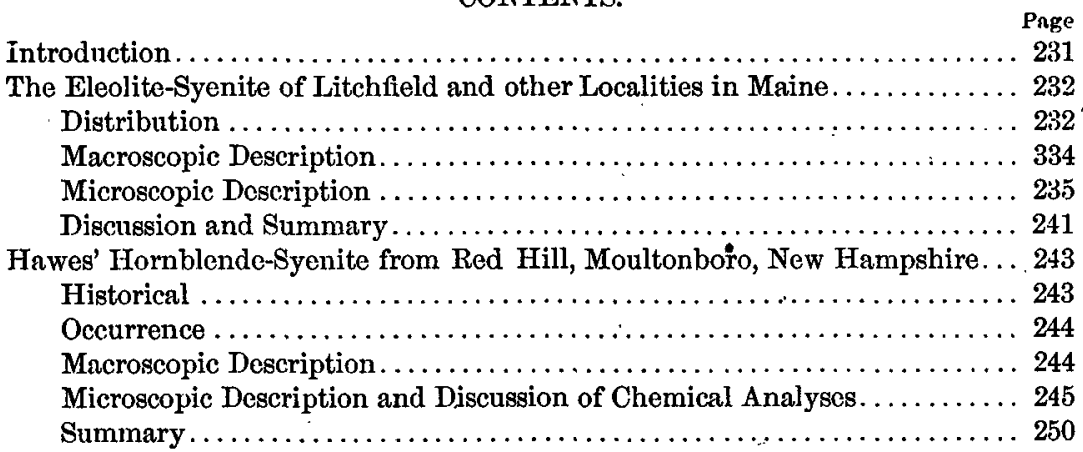

\section{INTRODUCTION.}

Of the two rocks whose petrographical descriptions are here given, one is from the well known occurrence near Litchfield, in Maine, and the other is the rock described by Hawes* as a hornblende-syenite from Red Hill, Moultonboro, New Hampshire.

In neither case has the writer examined the geological relations of the rocks sufficiently closely to warrant an expression of opinion regarding them. The New Hampshire locality has not been visited at all. The Maine occurrences have been visited twice, but on ncither occasion were more than a fow minutes spent at the several places where the rock is found.

The only excuses for the publication of this fragmentary paper at the present time are the interest that always pertains to the rare eleolite-

*G. W. Hawes : Min. and Lith. of New Hampshire, pt. iv of Goology of Now Hampshire, Concord, 1878 , p. 206.

XXXI-IButr. Grot. Soc. Am., Vor. 3, 1891. 
syenites and the desire to put on record the discovery of another locality for them within the United States.

Thanks are due to Messrs H. K. Morrell of Gardiner and R. G. Clough of Monmouth, Maine, for valuable aid in the collection of specimens of the Maine rock, and to Mr. M. M. Smith of Deland, Florida, and Mr. W. H. Mason of Moultonboro for information respecting the New Hampshire locality and for abundant material from it. Mr. J. S. Diller and Dr. F. W. Clarke of the United States Geological Survey have also done all in their power to help make the descriptions as complete as possible under the circumstances, the former gentleman having furnished thin sections of both the Maine and the New Hampshire rocks, and the latter having kindly provided analyses of both. I desire to express my appreciation of their aid, and also to thank Mr. G. P. Merrill of the National Museum for a chip from Hawes' original specimen of the New Hampshire rock, and Messrs L. G. Eakins, W. H. Melville and W. F. Hillebrand. for the careful chemical work that appears in the body of this article.

The Eueolite-Syenite of Litchfirdd and other Localities in Matne.

Distribution.-It is not quite certain that this rock has been found in place. Nearly all the specimens that have been sent abroad to the museums of this and other countries have come from bowlders or loose fragments lying on both sides of the road running from South Iitchfield post-office, in the town of Litchfield, Kennebec county, Maine, to the city of Gardiner, on the Maine Central railway, about six miles south of Augusta. The distance of the locality from South Litchfield is about three-quarters of a mile, and from Gardiner about eight miles. Here the fragments and bowlders are often quite large. Some are half buried in the soil on the gradual slope of a hill, while others lie on the surface. From the great abundance of the bowlders and their large size, together with their thick accumulation in such a small area, it is argued by many competent geologists that the parent ledge is somewhere in the near vicinity. However this may be, there can be no doubt that the rock is a schistose eruptive. In large pieces the schistosity is quite apparent, and even in hand specimens it may sometimes be readily detected. The characteristic mineral of this occurrence is cancrinite. The other two localities in which cancrinite predominates over sodalite and eleolite are southeast of South Litchfield, on the farms of Messrs Sawyer and Spaulding (see map, figure 1). In both of these cases the rock is in the shape of bowlders. At Sawyer's several large ones lie on the surface south of the road and within sight of it; at Spaulding's broken fragments are found built into stone walls. The underlying rock at both places is quite different 
from the eleolite-syenite, so that there is no probability of the latter being found at either place in situ. On the other hand, it is worthy of remark that the bowlders in both instances are directly in the course of the glacier* that passed over the region of South Litchfield.

Another well known locality, especially for that phase of the rock containing sodalite and large crystals of eleolite, is at Spears Corner, in West Gardiner, on the road from South Litchfield to Gardiner. On the

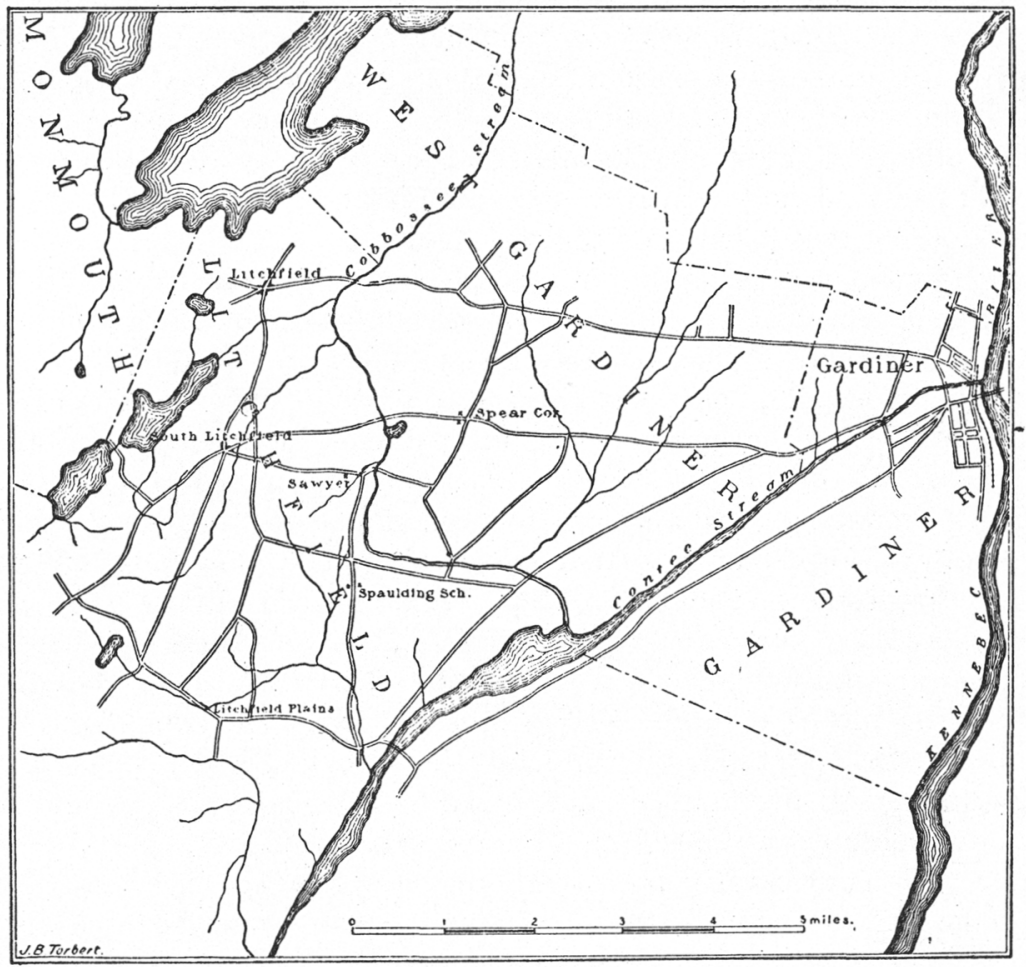

Figure 1-Map showing Distribulion of Eleolite-Syenite in the Towns of Litchfield and West Gardiner, Maine.

northern side of the road and about one hundred yards from it, in a clump of bushes near the bottom of a hill, there is a pile of large blocks resembling in their general arrangement the heap at South Litchfield. Most of these were originally completely buried in the sand and soil They are now well exposed through the active operations of collectors, but the soil around them has not been sufficiently removed to enable us

*Cf. T. C. Chamberlin: Map of a Portion of the Terminal Moraine, in 3d Ann, Rep. U. S. Geol. Survey, 1883, pl. xxxiii. 
to say positively whether the rock exists merely in bowlders or whether some of it may not be in place. A little north of east of South Litchfield the sodalite-bearing eleolite-syenite is again met with, on the eastern slope of a glacial ridge on the western side of the southern end of Cochnewagon pond in the town of Monmouth. Mr. Clough, who has carefully explored the region thereabout, asserts that the rock is found in a stretch of country running about northwest and southeast, with a width of only a few rods and a length of about two miles. Within these limits bowlders may be picked from any of the stone walls surrounding the fields. Beyond them the syenite has not yet been discovered. At Cochnewagon pond the bowlders of eleolite-syenite occur in considerable numbers with others of gneiss, granite and schist, principally at the base of a gravel and sand ridge that rests upon a foundation of slate. There is no question but that in this case the rock is not in place. It has undoubtedly been transported thither from somewhere toward the northwest.*

From a consideration of the statements above made, it would seem probable that all of the eleolite-syenite of the towns of West Gardiner, Litehfield and Monmouth has come from a region beyond the limits of these towns, and that nowhere within them does the rock occur in place.

Macroscopic Description.-The macroscopic appearance of the Maine eleolite-syenite is too well known to need much description. Its most noticeable features are the large masses of bright yellow cancrinite and deep blue sodalite and the brilliant plates of black mica that spot its otherwise almost snow-white surface. Here and there light brown zircon $\dagger$ crystals are imbedded among the other constituents, but they are by no means so numerous as museum specimens would seem to indicate. Among the lighter minerals that can be distinguished in the hand specimen, the most abundant is a white feldspar, often occurring in large columnar crystals from a quarter to a half inch in length. They have a distinct cleavage and a pearly luster on cleavage surfaces. Their specific gravity varies between 2.608 and 2.600. A partial analysis of pieces picked from a hand specimen is reported by Dr. Clarke $\ddagger$ to have yielded-

$\begin{array}{llllll}\mathrm{SiO}_{2} & \mathrm{Al}_{2} \mathrm{O}_{3} & \mathrm{~K}_{2} \mathrm{O} & \mathrm{Na}_{2} \mathrm{O} & \mathrm{H}_{2} \mathrm{O} & \text { Undet. } \\ 66.39 & 19.69 & 0.99 & 10.17 & 0.52 & (2.24)\end{array}$

This feldspar, which is undoubtedly albite, is the most prominent one in the rock, and is that which gives to it its characteristic peculiarities.

* Bowlders of the eloolite-syonite, sometimes containing cancrinite and at other times rich in sodulite, may also be found in almost any of the stone walls dividing the fiolds that lie within an area encompassed by lines joining the above described pcints.

t'These zircons were analyzed by Gibls (Pogg. Annalen, b. lxxi, 1822, p. 550) with the following result: $\mathrm{SiO}_{3}=35.26 ; \mathrm{ZrO}_{2}=63.33 ; \mathrm{Fe}_{2} \mathrm{O}_{3}=.79 ;$ undet. $=.36$.

f Am. Jour. Sci., 3d ser., vol. $x \times x i, 1886$, p. 268. 
Another of the prominent components is eleolite, which appears as irregularly shaped masses or as large columnar crystals with a length of as much as two inches and a breadth of half an inch. The irregular masses are distributed uniformly throughout the rock, while the crystals occur only in those portions in which the darker constituents are lacking (i. e., in acid "Schlieren"). In both cases the mineral possesses a gray color and the characteristic oily luster of eleolite, while its cleavage cracks are marked by interpositions of long dark needles of a black mica. Dr. Clarke* reports the eleolite to contain-

$\begin{array}{cccccccc}\mathrm{SiO}_{2} & \mathrm{Al}_{2} \mathrm{O}_{3} & \mathrm{CaO} & \mathrm{MgO} & \mathrm{K}_{2} \mathrm{O} & \mathrm{Na}_{2} \mathrm{O} & \mathrm{H}_{2} \mathrm{O} & \text { Total } \\ 43.74 & 34.48 & \text { tr. } & \text { tr. } & 4.55 & 16.62 & 0.86 & 100.25\end{array}$

All the constituents above mentioned are usually imbedded in a fine sugary aggregate of feldspar, of which there are several varieties, as will be shown later. Occasionally this fine grained aggregate is in very large quantity, when it appears as a groundmass surrounding the coarser grains. More frequently it is in smaller or larger areas between the other components, and in rare cases it is entirely absent. In this latter event the rock is a coarse grained mixture of large albite and eleolite grains and plates of lepidomelane. Its structure is massive, while that of all other varieties is schistose. In these schistose phases the plane of schistosity, as shown by the lamellar arrangement of the mica plates, is parallel to the contact of the rock with a lepidomelane schist, that is probably nothing other than a very basic portion of the rock magma that has been rendered schistose by pressure. In thin sections of all specimens in which the schistosity is marked, the foliation is plainly seen to be due to pressure; for not only are the feldspars marked by many series of curved twinning lamellæ, but the rock is also shattered, and in the cracks separating its different portions a large quantity of new feldspar has been deposited.

Microscopic Description.-The texture as revealed by the study of thin sections is thoroughly granitic, in that none $\dagger$. of the components possess crystal outlines, though many of the eleolite grains and some of those of the albite have quite well defined rectangular cross-sections. With the exception of the rare zircon, the lepidomelane is the oldest constituent, but whether this is followed by eleolite or albite it is difficult to determine, since in most cases the eleolite and the larger grains of albite are separated by areas of finer grained feldspars that are certainly later in origin than either one of the two minerals mentioned. It is

* Ibid., p. 262.

†'This statement applies only to the main mass of the rock, and is not true with regard to its acid or basic aggregations ("Schlieren"), where crystals of eleolite or of lepidomelane are not uncommon. 
probable, however, that the eleolite preceded the plagioclase in its crystallization.

The only dark colored component visible is a dark green biotite,* present not only in the large plates already mentioned, but also as inclusions in the eleolite. In basal sections the mineral is so dark as to be almost opaque. In other sections the ray vibrating perpendicular to the cleavage is bright greenish-yellow, while that vibrating parallel to the cleavage is dark green. The absorption, therefore, is $\mathfrak{a}<\mathfrak{b}=\mathfrak{r}$. The apparently uniaxial, negative interference figure opens slightly when revolved under crossed nicols, and the extinction of the mineral is sometimes inclined to the cleavage about $1^{\circ}$. The composition, according to Clarke, $\dagger$ is that of a very basic lepidomelane:

$$
\begin{array}{llllllllll}
\mathrm{SiO}_{2} & \mathrm{Al}_{2} \mathrm{O}_{3} & \mathrm{Fe}_{2} \mathrm{O}_{3} & \mathrm{FeO} & \mathrm{MnO} & \mathrm{CaO} & \mathrm{K}_{2} \mathrm{O} & \mathrm{Na}_{2} \mathrm{O} & \mathrm{H}_{2} \mathrm{O} & \text { Total } \\
32.35 & 17.47 & 24.22 & 13.11 & 1.02 & 0.89 & 0.70 & 6.40 & 4.67=100.83
\end{array}
$$

In natural light the mass in which the lepidomelane is imbedded appears as a colorless matrix, for the most part transparent, but clouded here and there with opaque white and yellowish decomposition products of eleolite and the larger albites (figure 1, plate 7). Under crossed nicols this apparently homogeneous groundmass resolves itself into large dull grains of eleolite and albite, and a finely granular aggregate of brilliantly colored feldspars and cancrinite, and a few perfectly isotropic grains of sodalite.

The eleolite, although it sometimes has a rectangular cross-section, is usually in allotriomorphic grains, whose outlines are rendered more or less jagged by projections extending out into the areas between the surrounding grains. The inclusions that crowd it are glass and fluid cavities, the latter frequently containing movable bubbles, long narrow plates of lepidomelane, with their longer directions parallel to the vertical axes of their hosts, and various decomposition products, among which may be mentioned a few brightly polarizing fibers of some zeolitic mineral and an occasional flake of muscovite. Sodalite and cancrinite were also met with, in a single instance, as alteration products of the eleolite; but since they were not entirely inclosed by this mineral they can scarcely be spoken of as inclusions. Under crossed nicols many of the larger grains are discovered to be intergrown with a twinned feldspar, which,

\footnotetext{
* In spite of earnest search through sixteen sections of the Litchfield rock, no trace of any mica but this could be discovered although both Rosenbuseh (Mikroskopisehe Physiographie, b. ii 1887, p. 85) and Clarke (Am. Jour. Sci., 3d ser., vol. xxxiv, 1887, p. 134) mention the existence of two micas in it. In one section of the Cochnewagon rock the biotite is dark brown instead of dark green. It presents the pleochroism of ordinary biotite, and is certainly not a lepidomelane. The rock is much decomposed, and is different in so many of its features from the other specimens collected at this place, as well as at the localities in Litchfield and West Gardiner, that its consideration is entirely omitted from the present discussion.

†Am. Jour. Sci., 3d ser., vol. xxxiv, 1887, p. 133.
} 
judging from the mass-analysis of the rock (page 241), must be albite. Many small areas of this inclosed feldspar occur with their axes in the same direction. Their material is not sharply defined from the surrounding eleolite, but appears to pass into it by insensible gradations.

Of the feldspars the most abundant is the cloudy albite occurring in the columnar crystals already mentioned. In the thin section these possess long quadrangular forms, characterized by a series of remarkably fine twinning lamellæ, whose close study affords the best evidences of the pressure to which the entire rockmass has been subjected. Individual twinning plates often wedge out and disappear, while others spring from the sides of cracks. Other lamellæ are bent and bowed, some are broken off sharply at cleavage cracks, while still others in the interior of the grains are crossed by a second series of striations running nearly at right angles to the first ones. There are also indications that some of these grains are composed of two feldspars, for their resemblance to Brögger's* pictures of cryptoperthite and microcline-microperthite is very striking. The character of the two feldspars, however, has not been certainly established, though it is quite probable that albite and microcline form one of the combinations. The specific gravity and composition of these albites have already been given (page 234). Since they contain but one per cent of $\mathrm{K}_{2} \mathrm{O}$ it is quite clear that the potash molecule cannot play a very great rôle in the intergrowths.

The difficulty in determining the true nature of the constituent feldspars in these combinations is due principally to the fact that the large grains are penetrated in all directions by jagged embayments of a pellucid plagioclase with broader twinning lamellæ than those of the turbid phenocrysts and without inclusions of any kind. Small areas of this glassy feldspar occur all through the large albites, so that the latter appear to be completely saturated with the former. The saturating feldspar often has two sets of twinning striations. It polarizes in gray and blue tints, and always has ragged outlines when it does not grade into the enclosing albite. It seems impossible to assign any but a secondary origin to the included material. The large crystals are so corroded by it that in some cases but a slight film of the original substance separates the different areas of the new substance from each other. The different areas of the new feldspar, moreover, are optically continuous with one another, as are also different portions of the enclosing albite, so that the polarization of the intergrowths is very like that of quartz and orthoclase in micropegmatite.

Besides this saturating feldspar there are other feldspars occurring in small grains, in some instances forming a sort of mosaic in which all the 
other components of the rock lie, and sometimes filling what were apparently cracks in the rock mass (figure 2, plate 7). All these grains polarize with bright colors, and all are clear and perfectly transparent. They aro all of about the same size, none ever have crystallographic outlines, and all are younger than the large crystals of albite that have been mentioned so frequently. In rare cases this mosaic itself is imbedded in a finer mosaic of the same character, except that it is saturated with cancrinite. The structure produced by the imbedding of the larger components of the rock in this fine grained mosaic is strongly suggestive of the mortar structure of Törnebohm, which is regarded by this author as a certain indication that the rock exhibiting it has been subjected to pressure and shearing.

Two feldspars are distinctly observable in the mosaic, and a third one may exist. The two undoubtedly present are so much alike in appearance that it is difficult in many instances to determine the nature of a particular grain. The number of untwinned grains however indicates the presence of an orthoclase, while the number of grains with straight narrow twinning lamellæ points to the existence of a plagioclase. Another feldspar almost surely present is microcline. It is in slightly larger pieces than the other two, and is well marked by the double twinning. It is impossible to speak more positively as to the nature of these feldspars, as cleavage cracks are not common, crystallographic outlines are never present, and the twinning lamellæ are bowed and bent to such an extent that readings of extinction angles are not decisive.

In separation by the Thoulet solution two lots of feldspar fell when the density of the liquid was 2.622 and 2.56 respectively. That which fell at 2.622 consists of grains usually striated in a single direction and of others in which no striations' are noticeable. The latter extinguish at $19^{\circ}$ from the cleavage, and show between crossed nicols the bar of an axial figure. Their analysis, made by Mr. W. H. Melville, of the United States Geological Survey, is that of a very pure albite $(I)$ :

\begin{tabular}{|c|c|c|c|c|}
\hline & I. & Albite. & II. & Orthoclase. \\
\hline \multirow[t]{2}{*}{ 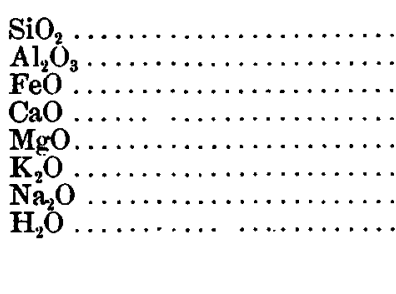 } & $\begin{array}{r}68.28 \\
19.62 \\
.23 \\
.31 \\
.09 \\
.39 \\
10.81 \\
.09\end{array}$ & 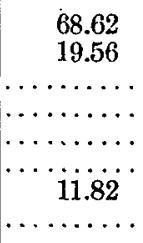 & $\begin{array}{r}65.14 \\
18.19 \\
.25 \\
.33 \\
.16 \\
14.14 \\
1.68 \\
.17\end{array}$ & 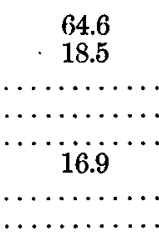 \\
\hline & 99.82 & 100.00 & 100.06 & 100.00 \\
\hline
\end{tabular}


The powder that fell at 2.56 contains some untwinned grains and many with the twinning striations of microcline. Its composition is given under column II. As will be seen by comparison with the figures for orthoclase, this mineral also is very pure. There can be no doubt that it is a potassium feldspar, and it is probable that it crystallizes in both monoclinic and triclinic forms.

In view of the fact that eleolite-syenite is defined as a rock consisting essentially of orthoclase and eleolite, it becomes of importance to determine whether the potash feldspars in the Maine rock are primary or secondary. It is very evident that they are younger than the eleolite and the large crystals of albite, and are of the same age as the albite grains in the mosaic. Their small grain, perfect transparency, lack of cleavage, and the method of their occurrence in narrow stringers and small areas between the undoubted primary constituents point to a secondary origin for all the minerals in the mosaic. The arrangement of these is, however, somewhat peculiar, in that in nearly every case they are more or less lenticular and their long axes are rudely parallel to the long directions of the areas which they form. This would indicate that the pressure by which the rock was made schistose acted after the feldspar grains of the mosaic were formed. The explanation of the phenomenon seems to be that the rock which originally consisted of eleolite, albite, lepidomelane, and perhaps some orthoclase or other feldspar, was subjected to great pressure attended by motion, that it was broken and shattered, and that the fragments were rolled upon one another, and at the same time albite and orthoclase were deposited in all the crevices as they were formed. The pressure and motion continued until all the newly formed grains became oriented, and some had developed in them twinning lamellæ. From all the evidence at hand it would appear that the microcline in the Litchfield rock is merely an orthoclase with secondary crosstwinning.

An indication of the correctness of this view is the fact that where the feldspathic mosaic is absent the rock is massive and not schistose-i.e., where pressure has not produced foliation there is an absence of the small grains of feldspar composing the mosaic.

The only two constituents remaining to be described are cancrinite and sodalite. The latter may usually be recognized by its light blue color in natural light, though at times its tint is so pale that it can be detected only by the contrast afforded by the colorless minerals associated with it, which appear to be slightly tinged with yellow. Under crossed nicols it is perfectly isotropic. No idiomorphic forms occur, but the substance extends irregularly around the other components including them, as augite does the feldspar in many diabases. The most abun- 
dant of the minerals imbedded in the sodalite are irregular grains of plagioclase, little plates of lepidomelane and cancrinite, and a few small flakes of a brightly polarizing micaceous substance. Eleolite is often intergrown with the sodalite in such a way that a large number of apparently isolated areas of the former polarize together. The relation of the sodalite to the other constituents leaves no doubt as to its age with respect to these. It is certainly younger than any of them. Therefore, since it is younger than components that are themselves younger than the eleolite, and at the same time is intergrown with the latter mineral, as described above, it must be an alteration product of this. The beautiful pieces that have been sent to the museums as mineral specimens are certainly secondary, for in them the sodalite is found on the faces of jointcracks, and in most cases it extends back from these surfaces into masses of eleolite that lie near them.

The composition of compact masses of sodalite taken from seams in the Maine rock was found by Clarke* to be:

$$
\begin{array}{lllllll}
\mathrm{SiO}_{2} & \mathrm{Al}_{2} \mathrm{O}_{3} & \mathrm{Na}_{2} \mathrm{O} & \mathrm{K}_{2} \mathrm{O} & \mathrm{Cl} & \mathrm{H}_{2} \mathrm{O} & \text { Total }-(\mathrm{O}=\mathrm{Cl}) \\
37.33 & 31.87 & 24.56 & 0.10 & 6.83 & 1.07=100.22
\end{array}
$$

The white alteration product of sodalite described by Dr. Clarke $\dagger$ under the name of hydro-nephelite was not seen in any of the sections examined. This is probably owing to the fact that the sections were all made from pieces of the rock taken from the interior of blocks at some distance from seams or joint cracks. Its microscopical description is so well given by Diller $\ddagger$ and Brögger, $\S$ however, that little could be added to it by study of material in the writer's possession.

The cancrinite is not distinguishable from feldspar in ordinary light; except in thick sections, where it possesses a slightly yellowish tinge. In thinner sections it is colorless, transparent and without inclusions, other than pores containing liquid inclosing movable bubbles. Of these there are two kinds, viz, a series of long quadrangular and spindle-shaped cavities arranged in lines with their long directions parallel to the vertical axes of the cancrinite grains, and round and irregularly shaped ones running in lines that are usually sharply inclined (often perpendicular) to these axes. Under crossed nicols the mineral polarizes with very brilliant colors, and extinguishes parallel to the two well marked cleavages that traverse it. The grains, which are all allotriomorphic and elongated in the direction of the lateral axes, are found intermingled with the feldspar of the mosaic and in larger pieces scattered between

*Am. Jour. Sci., 3rd ser., vol xxxi, 1886, p. 264.

$\dagger$ lbid., p. 265.

Ibid., p. 266.

\& Zeits. d. Kryst., b. xvi, 1890, pp. 234 and 636. 
the eleolites and the larger albites. Dr. Clarke,*arguing from the result of his analysis of the mineral, declares that most of the cancrinite of the Ijitchfield rock is an alteration product of eleolite; while Rosenbusch, $\uparrow$ on the other hand, cites it as an especially fine example of primary cancrinite. The microscope shows conclusively that some of the cancrinite has resulted from the alteration of eleolite. The most of it, however, is so far removed from eleolite that its relation to this mineral has not been discovered. It occurs principally in the mosaic, which has been thought to be of secondary origin, and is the youngest of its constituents, with the exception of sodalite. It has certainly crystallized from the magma that yielded the other minerals of the mosaic, and in this sense is original, but its chemical components may nevertheless have come from some of the eleolite that was destroyed at the time of the formation of the mosaic.

The composition of the commonest type of the cancrinite, the bright yellow granular variety, is as follows:

$\begin{array}{ccccccccccr}\mathrm{SiO}_{2} & \mathrm{Al}_{2} \mathrm{O}_{3} & \mathrm{Mn}_{2} \mathrm{O}_{3} & \mathrm{Fe}_{2} \mathrm{O}_{3} & \mathrm{CaO} & \mathrm{Na}_{2} \mathrm{O} & \mathrm{K}_{2} \mathrm{O} & \mathrm{MgO}^{2} & \mathrm{H}_{2} \mathrm{O} & \mathrm{CO}_{2} & \text { Total } \\ 37.22 & 28.32 & \text { tr. } & \text { tr. } & 4.40 & 19.43 & 0.18 & 0.07 & 3.86 & 6.22=99.70\end{array}$

Discussion and Summary.-A noticeable fact in connection with this rock is the absence of sphene, hornblende and augite. The former is present in nearly all normal eleolite-syenites, with the exception of those from Kangerdluarsuk in Greenland and from Fünfkirchen in Hungary, while one of the last two is usually found, even though biotite be the most prominent of the bisilicates present. Another fact of interest in connection with the Maine rock is the great preponderance of albite among the feldspars. An analysis of the most common phase of the rock by Mr. L. G. Eakins gave:

$$
\begin{aligned}
& \mathrm{SiO}_{2}=60.39 \\
& \mathrm{Al}_{2} \mathrm{O}_{3}=22.51 \\
& \mathrm{Fe}_{2} \mathrm{O}_{3}=.42 \\
& \mathrm{FeO}=2.26 \\
& \mathrm{MnO}=.08 \\
& \mathrm{CaO}=.32 \\
& \mathrm{MgO}=.13 \\
& \mathrm{~K}_{2} \mathrm{O}=4.77 \\
& \mathrm{Na}_{2} \mathrm{O}=8.44 \\
& \mathrm{H}_{2} \mathrm{O}=.57 \\
& \mathrm{CO}_{2}=- \text { tr. } \\
& \text { Total }=99.95
\end{aligned}
$$


From this we calculate that the ingredients are intermingled in the proportions shown below:

\begin{tabular}{|c|c|c|c|c|c|c|c|c|}
\hline & Rock. & 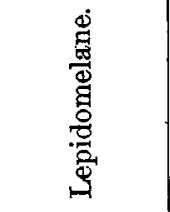 & 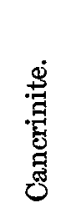 & 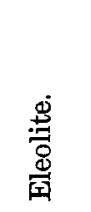 & 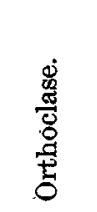 & 串 & 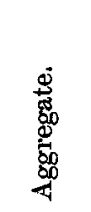 & 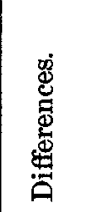 \\
\hline \multirow{9}{*}{$\begin{array}{l}\mathrm{SiO}_{2} \ldots \ldots \\
\mathrm{Al}_{2} \mathrm{O}_{3} \ldots \ldots \\
\mathrm{Fe}_{2} \mathrm{O}_{3} \ldots \\
\mathrm{FeO} \ldots \ldots \\
\mathrm{MnO} \\
\mathrm{CaO} \ldots \\
\mathrm{MgO} \ldots \ldots \\
\mathrm{M}_{2} \mathrm{O} \ldots \ldots \\
\mathrm{Na}_{2} \mathrm{O} \ldots \ldots \\
\mathrm{H}_{2} \mathrm{O} \ldots \ldots \\
\mathrm{CO}_{2} \ldots \ldots \ldots\end{array}$} & \multirow{7}{*}{$\begin{array}{c}60.39 \\
22.57 \\
.42 \\
2.26 \\
.08 \\
.32 \\
.13 \\
4.77 \\
8.44 \\
.57 \\
\text { tr. }\end{array}$} & $\begin{array}{l}2.264 \\
1.223\end{array}$ & $\begin{array}{l}.744 \\
.566\end{array}$ & $\begin{array}{l}7.436 \\
5.862\end{array}$ & $\begin{array}{r}17.588 \\
4.911\end{array}$ & 32.091 & $\begin{array}{l}60.123 \\
21.783\end{array}$ & $\begin{array}{l}.267 \\
.787\end{array}$ \\
\hline & & \multirow{3}{*}{$\begin{array}{r}2.444 \\
.071 \\
.063\end{array}$} & \multirow{2}{*}{$\ldots$} & & \multirow[t]{2}{*}{.067} & \multirow[t]{2}{*}{.108} & 2.619 & \multirow{6}{*}{$\begin{array}{r}.014 \\
.009 \\
-.066 \\
.047 \\
-.068 \\
-.655 \\
-.061 \\
-.124\end{array}$} \\
\hline & & & & & & & .071 & \\
\hline & & & .088 & & $\begin{array}{l}.089 \\
.043\end{array}$ & $\begin{array}{l}.146 \\
.040\end{array}$ & .386 & \\
\hline & & .049 & .004 & .773 & 3.818 & .194 & 4.838 & \\
\hline & & .448 & .388 & 2.825 & .454 & 5.080 & 9.195 & \\
\hline & & .324 & .077 & .146 & .044 & .040 & .631 & \\
\hline & 99.95 & $\begin{array}{l}6.886 \\
.170(=0)\end{array}$ & 1.991 & 17.042 & 27.014 & 46.920 & 99.853 & \\
\hline & & 7.056 & & & & & & \\
\hline
\end{tabular}

viz : 7 per cent of lepidomelane, 2 per cent of cancrinite, 17 per cent of eleolite, 27 per cent of orthoclase (and microcline), and 47 per cent of albite. As was indicated by the microscopic study, no plagioclase other than albite is present, and this, as is seen, is largely in excess of the orthoclase.

The rock, then, while certainly to be classed with the eleolite-syenites, is nevertheless very unlike those that have been described from other localities. It consists essentially of lepidomelane, eleolite and albite among its undoubted primary components, and of orthoclase, albite, cancrinite and sodalite among those of probable secondary origin. Even though the orthoclase should be regarded as primary, it is not in sufficient quantity to affect to any considerable degree the character of the rock. Its structure is seen to be thoroughly granitic where the deformation produced by pressure is not so great as to obscure all traces of its original character. Although, according to Rosenbusch's scheme, its composition would carry the rock among the theralites, its characteristics certainly point to the eleolite-syenites as its nearest relatives. The sodalite and cancrinite of the eleolite-syenites are abundant in the Maine rock and the dark color that is to be expected in the more basic plagioclase-eleolite rack is lacking. The plagioclase of the former is the most acid one known, 
while the more basic members of this group of minerals are entirely wanting. Consequently, in spite of the great predominance of albite over orthoclase, we are quite justified in calling our rock an eleolite-syenite. Its large percentage of albite, however, and its possession of but one bisilicate constituent, and that a biotite (lepidomelane), seen to distinguish it as a very well defined variety of eleolite-syenite, as well characterized in the hand-specimen as in the thin section. Its peculiarities are so strongly marked that the rock seems worthy of a distinctive varietal name, for which no more appropriate one can be found than litchfieldite, derived from the familiar locality-Litchfield-whence nearly all the specimens in the museums were obtained.

\section{Hawes' Hornblende-Syenite from Red Hill, Moultonboro, New HAMPSHIRE.}

Historical.-The New Hampshire rock was described by Hawes as a hornblende-syenite in these words:

"A beautiful variety comes from Red hill, in Moultonborough. It is composed essentially of orthoclase, which exists in thin tabular twinned crystals, which mostly lie in one plane, and consequently give to little specimens of the rock a stratified appearance. The hornblende, which is irregularly distributed, is black, but in thin sections it is deep yellow, and it incloses more or less biotite in its mass. Microscopic grains of blood-red hematite and black magnetite and crystals of apatite are de'ected, and by the aid of polarized light some plagioclase is found to be present. Only a very little quartz is seen in some little angular corners made by the melting of the straight edges of the orthoclase crystals. Little, partially crystallized grains of sphene are found, and some of the grains of hornblende are shown by polarized light to consist of two parts in twin relationship. As there are large accumulations of this rock, it is one of considerable importance."

Nothing is said of the method of occurrence of the rock, though similar ones are described as existing in dikes.

Mr. J. S. Diller, in his search for a typical syenite for the educational series of the United States Geological Survey, examined specimens of the Red hill rock sent him by Professor W. O. Crosby, of the Massachusetts Institute of Technology, who obtained them in turn from a man who was instructed to collect the material from Hawes' original ledges. A few minutes' survey of the specimens. revealed the presence of blue sodalite, and a tiny piece treated with hydrochloric acid gelatinized easily. Sections of the rock were then made and turned over to the writer for investigation, the results of which are recorded in the present article. That the material furnished by Professor Crosby represents Hawes' rock is shown by its comparison with a specimen in the National Museum labeled in Hawes' own handwriting. 
Occurrence.-As indicated in the title, the rock studied occurs at Red hill, just north of Center harbor, in the town of Moultonboro, Carroll county, New Hampshire. No definite information is available as to the amount of the rock found in this place, but from published descriptions of Red hill it seems likely that the entire eminence is composed of it; for we read in the "History and Description of New England" * that "towering up some 2,000 feet above the level of the sea is Red hill, formed of a beautiful syenite, in which the feldspar is of a gray-ash color."

Macroscopic Description. - So few specimens of the rock have been seen that it will be impossible to describe the characteristics of its mass as a whole. We shall have to content ourselves with a rapid survey of the specimens at hand, and with a sufficiently detailed study of their thin sections to prove conclusively that the rock is not a hornblende-syenite as supposed by Hawes, but is an eleolite-syenite as surmised by Diller. The six slides examined as representing the three types of the rock thus far obtained are, however, so nearly alike in their essential peculiarities that they may evidently be regarded as illustrative of the principal features of the occurrence.

The specimens furnished by Professor Crosby approach nearer in appearance to some varieties of the Arkansas eleolite-syenites than to any rocks with which the writer is acquainted. They are moderately coarse grained, pinkish-gray crystalline masses, containing irregular patches of an easily cleavable, lustrous, jet black mineral that sometimes measure a quarter of an inch in diameter and sometimes are microscopic in dimensions. In the pinkish-gray portion large even surfaces of a twinned feldspar are easily discernible. These are cross-sections of columnar or tabular crystals, and are the special features of the rock that are most prominent. Besides these are scattered here and there dull, irregular masses of eleolite, and occasionally tiny blue areas of sodalite. Neither sodalite nor eleolite is so common as in the litchfieldite, while cancrinite has not been detected in any specimens of the New Hampshire rock.

The piece in the National Museum corresponds more nearly to Hawes' original description than do the specimens collected more recently. A fragment of it shows a well defined banding, which is due to the flattening of the feldspars and the dark constituents and their arrangement in planes parallel to each other. From the bending of the flat feldspar plates and the existence of many small fractures crossing them at right angles to their long dimensions it would seem that the platy structure is the result of pressure without much attendant motion. The single thin section examincd, however, affords no support to this supposition.

A third variety of the rock has recently been collected by Mr. M. M.

* Coolidge and Mansfield: History and Description of New Fngland, vol. 1, 1859, p. 585. 
Sinith, who has kindly furnished to the writer all the material desired. In a letter accompanying the specimens Mr. Smith says:

"The rock I obtained on the northeastern side of Red hill, on land belonging to Mr. W. H. Mason. The ledge lies in the pasture on the southwestern side of the road."

In this variety the structure is more nearly granular than in the case of either of the others, and the rock is much fresher. The large twinned feldspars that are so characteristic of the first two varieties described are lacking in this. The groundmass of the hand-specimen is of a grayish-white color and is composed of brilliantly glistening facets of an untwinned feldspar and small dull gray areas of eleolite. Occasionally tiny Carlsbad twins of orthoclase may be detected, but these are rare. In this groundmass are large columnar crystals of a feldspar like that of the smaller grains, and large black grains of hornblende, frequently with idiomorphic outlines. The resemblance of this rock to a typical hornblende-syenite is so close that there need be no surprise that it was called such by so careful an observer as Hawes. The eleolite is not recognizable in the hand-specimen until after its presence has been ascertained by microscopical and chemical tests.

Microscopic Description and Discussion of Chemical Analyses.-A single glance at its thin sections shows the Red hill rock to be quite different in structure as well as in composition from the Maine eleolite-syenite. Its components are a light-colored augite, bright green and dark brownishgreen hornblende, brown biotite, feldspar, eleolite and sodalite as essentials, and magnetite, sphene, apatite and leucoxene as accessories. The oldest of these are magnetite, apatite and sphene. The former is in little irregular grains and accumulations of grains, and the sphene is in rounded and irregular masses and in double wedge-shaped crystals, with the usual color and pleochroism of this mineral. The apatite is present in the familiar colorless prisms so well known. All occur as inclusions in all the other constituents, but they are more frequently in and around the aggregates of the bisilicates than elsewhere.

Next in age follow the iron compounds. These, as has been stated, are augite, hornblende and biotite, which, together with apatite, magnetite and leucoxene, form aggregates or accumulations, the primary constituents of which separated from the magma some time before the elements of the light-colored groundmass in which they are imbedded.

But little of the augite remains in the rock. That which is present exists as very light green, almost colorless cores, whose peripheries are fringed with bright green hornblende. The maximum extinction observed in these cores is $37^{\circ}$. In all cases the augite lies imbedded in an irregular aggregate of the green homblende, biotite and leucoxene, of which the 
first and last mentioned minerals are no doubt alteration products of the augite. The bright green hornblende is strongly pleochroic in bright green tints in sections parallel to the vertical axis and in green and brownish-green tints in basal sections. The cross-cleavage of hornblende is very apparent in the latter, and sometimes this is accompanied by the rectangular cleavage of augite. The inclusions of this hornblende, as of the augite from which it is derived, are apatite and small grains of magnetite.

Intermingled with the green hornblende and including large masses of it are large and small, plates of biotite, whose strong pleochroism is in very dark brown and bright yellow colors. Its extinction, determined by means of the quartz ocular, is parallel to the cleavage, but its axial figure opens slightly when revolved between crossed nicols. There is no evidence that the mineral is an alteration product of augite. Its relation to the green hornblende and leucoxene which it inclosed declares it to be younger than these, or, more properly speaking, than the augite from which these are derived. In addition to the green hornblende and the leucoxene,* the biotite also includes crystals of apatite and sphene that are probably original separations from the magma.

Another form of the biotite is surrounded by green hornblende in such a way that we must suppose a small quantity of the latter to have resulted from the alteration of the former, for the borders of the mica, like those of the augite, are fringed with a narrow rim of the hornblende.

Of the nature of the brownish-green hornblende but little has been learned. It is frequently in idiomorphic grains, bounded by the usual forms found on hornblende, and is often twinned according to the ordinary law. Its color in prismatic sections is dark green, with a slight tinge of yellow in a direction highly inclined to the cleavage, and dark brown, almost opaque in directions nearly parallel to it. In basal sections the ray parallel to $\mathfrak{a}$ is dark green, while that parallel to $\mathfrak{b}$ is almost completely absorbed. The scheme for the absorption is consequently $\mathfrak{c}=\mathfrak{b}>\mathfrak{a}$. The extinction is high, certainly above $24^{\circ}$, and the inclusions imbedded in the mineral are those common to the other bisilicates. Around its edges are sometimes discoverable little masses of iron oxides that may indicate magmatic resorption. This variety of hornblende was seen in its greatest perfection in the slide made from Hawes' original specimen. Here it occurs not only in the aggregated basic concretions, but also in isolated idiomorphic grains, commonly associated with eleolite or its decomposition products. It is also abundant in the specimens obtained by Mr. Smith. From the fact that the mineral occurs so frequently in isolated

\footnotetext{
* The distinction here made between the two titanium minerals is merely one of origin, the granular secondary substance being called lewcoxene, and the cryatallized original titanate being denominated sphene.
} 
idiomorphic grains, having traces of having undergone resorption, we must conclude that, like the augite and the biotite, it is primary in origin and not secondary, as is the bright green hornblende.

The colorless components forming the mass in which the dark aggregates lie are sodalite, eleolite and feldspar, whose relative ages are probably in the order named. The first two mentioned are in small quantity as compared with the feldspar, though the eleolite is in sufficient abundance to characterize the rock as an eleolite-syenite. When unaltered it is perfectly colorless. It occurs occasionally in prismatic * forms between the feldspar, but more frequently as irregular masses associated with the basic constituents of the rock and often surrounding them, and also as grains included in the intergrowths of albite and orthoclase. The time of its formation consequently was between that of the bisilicates and that of the feldspar. The inclusions in the eleolite, besides the sphene and bisilicates already mentioned, are flakes of a brightly polarizing, fibrous substance, and tiny grains of calcite. Both of these are decomposition products of their host, for as they increase in quantity the eleolite surrounding them gradually loses its transparency and other characteristics until finally it passes into a cloudy mass, consisting largely of a felt of the brightly polarizing fibers, studded here and there with grains of calcite.

The sodalite is distinguishable from the fresh eleolite only in polarized light, where it remains dark during an entire revolution. It occurs under conditions that are exactly similar to those under which eleolite exists. It is found cementing the bisilicates in the basic aggregates, and is often present as inclusions in the feldspar. Rarely is it discovered in pieces of any size between grains of feldspar. Perhaps its most characteristic form of occurrence is as inclusions in the feldspar. These are usually very irregular in shape, but occasionally the grains show very clearly the traces of dodecahedral planes (figure 2). That the isotropic grains are sodalite and not some other regularly crystallizing mineral may be beautifully shown by Lemberg's test, $\uparrow$ in which a dilute acid solution of silver nitrate is allowed to come in contact with the uncovered section. In a portion of a slide treated in this way the isotropic grains were covered with a white coating of silver chloride, while the nepheline grains remained unaffected.

The sodalite, like the eleolite, is older than the feldspars, but is younger than the bisilicates. A single observation upon the relative ages of the first two mentioned minerals indicates that the sodalite preceded the eleolite in the time of its formation.

\footnotetext{
* It is probably this that was taken by Hawes for quartz (see description, p. 243).

† J. Lemberg: Zeits, d. d. geol. Gesell., b. xlii, 1890, p. 738.

XXXIII-BuLl. Grol. Suc. Am., VoL. 3, 1801.
} 
The feldspar was the latest of all the components to crystallize. It constitutes about 80 per cent of the entire rock, and occurs almost exclusively in large Carlsbad twins, with irregular outlines. In spite of the abun-

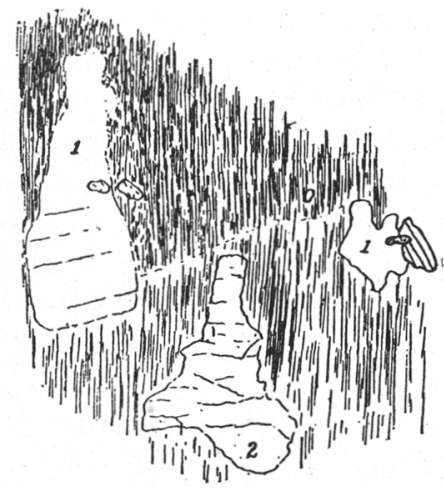

Figure 2.-Occurrence of Nepheline and Sodalite in Feldspar. $1=$ Nepheline $; 2=$ Sodalite.

dance of apparent crystals in the hand-specimen, the thin section contains no grains with idiomorphic forms. All have such shapes as are permitted them by surrounding grains; so that we have in this feldspathic portion

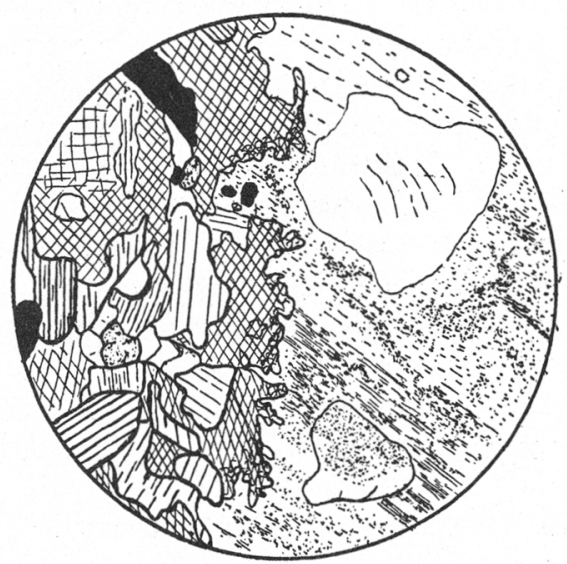

Figure 3.-Eleolite Syenite from Red Hill.

The slide shows a portion of a basic accumulation consisting of biotite, hornblende, augite (rectangular cleavage), sphene (stippled), and magnetite.

of the rock an interpenetrating mass of large twinned grains, which have, however, a well marked extension in a single direction, and thus a 
columnar habit. In natural light the substance of the feldspar appears to be homogeneous, but under crossed nicols it is seen to be an intergrowth of two very different substances with extinctions corresponding to orthoclase.and albite. The orthoclase has suffered the effects of alteration to a much greater extent than has the albite, and in consequence has often entirely disappeared, while its place is now occupied by a cloudy aggregate of kaolin or of micaceous minerals. The albite remains quite fresh, and so includes these secondary products. The other inclusions of the albite, as well as those of the orthoclase, are the eleolite and sodalite grains already referred to, with crystals of sphene, apatite, and dark green hornblende, and an occasional rounded grain of zircon ; besides, of course, the usual liquid inclusions. It is not certainly known whether other feldspars than those mentioned are present or not, but it is assured by the analysis of the rock that if they do occur it is in but very small quantity. A separation of the feldspar from the powdered rock by a heavy solution points to the same conclusion; for while a great lot of material fell when the density of the solution was between 2.571 and 2.586, but a trifling quantity was precipitated on either side of these limits. An analysis of that portion of the powder whose specific gravity was $2.57-2.58$ showed it to consist partly of eleolite and partly of feldspar. These were separated by extraction with hydrochloric acid and digestion with sodium carbonate, and then analyzed by Mr. W. F. Hillebrand, who reports these figures:

\begin{tabular}{|c|c|c|}
\hline & Nepheline. & Feldspars. \\
\hline 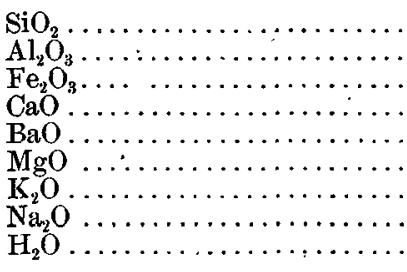 & $\begin{array}{c}45.31 \\
32.67 \\
\cdots \ldots \ldots \cdots \\
2.00 \\
\cdots \ldots \ldots \cdots \\
.16 \\
5.70 \\
12.60 \\
1.56 \text { (calc.) }\end{array}$ & $\begin{array}{r}66.85 \\
19.50 \\
.13 \\
.11 \\
.07 \\
\text { tr. } \\
5.80 \\
7.44 \\
.31\end{array}$ \\
\hline Total. & 100.00 & 100.21 \\
\hline
\end{tabular}

From the result of this analysis it is quite plain that the insoluble portion of the powder is a mixture of orthoclase and albite molecules; and since the microscope shows the presence of two feldspars in each grain, it is equally certain that these molecules are in the form of intergrowths of orthoclase and albite and not in their combination anorthoclase. 
An analysis of the rock made by the same chemist gave:

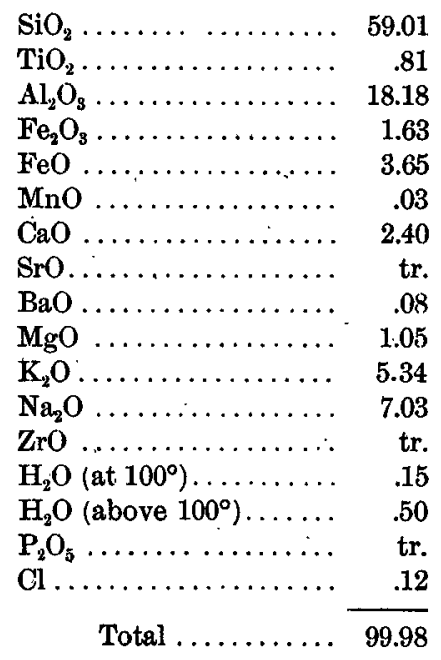

A single glance at this column affirms the statement above made that if any plagioclase other than albite is present in the rock it must be in very small quantity, for the $2.40^{\circ}$ per cent of $\mathrm{CaO}$ indicated by the analysis is not more than enough to satisfy the demands of the 15 per cent of augite, hornblende, biotite and sphene that are known to exist there. Again, the percentage of $\mathrm{K}_{2} \mathrm{O}$ is less than that of $\mathrm{Na}_{2} \mathrm{O}$. Even after allowing for the excess of $\mathrm{Na}_{2} \mathrm{O}$ over $\mathrm{K}_{2} \mathrm{O}$ in the eleolite and the presence of sodium in the sodalite, there still would remain a larger proportion of $\mathrm{Na}_{2} \mathrm{O}$ than of $\mathrm{K}_{2} \mathrm{O}$. This would necessarily imply that albite is in excess over orthoclase.

Summary.-Although but few specimens of the Red hill, New Hampshire, rock have been examined, enough is known of the occurrence to enable us to declare it to be an acid eleolite-syenite, containing a larger proportion of albite than of orthoclase. Its essential constituents in the order of their ages are augite, hornblende, biotite, sotalite, eleolite and the two feldspars, orthoclase and albite. Its accessory primary components are apatite, crystallized sphene, magnetite and occasionally zircon, and its secondary constituents granular sphene and bright-green hornblende, besides fibrous decomposition products of eleolite and of orthoclase. It differs from litchfieldite in being less acid, in containing a little less albite and more undoubtedly original orthoclase, and especially in the possession of augite, hornblende and sphene, all of which are important elements in the composition of most eleolitc-syenites. Besides, the New 
Hampshire rock contains original sodalite, while this mineral in the Maine rock is principally secondary. The former therefore is more nearly a normal eleolite-syenite than is the latter, although it possesses an abnormally high percentage of albite, as indicated by the high percentage of silica and the low percentage of alumina, together with an excess of soda over potash. 


\section{Explanation of Plate 7 .}

Figure 1.-Litchfieldite in natural light. The dark mineral is lepidomelane. The large gray areas in the lower left of the picture and the light areas surrounded by the mica are eleolite. Everything else is albite. $\times .33$.

Figure 2.-Litchfieldite under crossed nicols. Here the eleolite is easily distinguished from the plagiaclase, since the former polarizes with a uniformly dark gray tint. Nearly all of the material included between plates of the lepidomelane are thus seen to be this mineral. The very light colored aggregate in figure 1 breaks up, under crossed nicols, into a mosaic of small plagioclase grains, that surrounds the basic elements of the rock and separates them from each other. $\times .33$. 


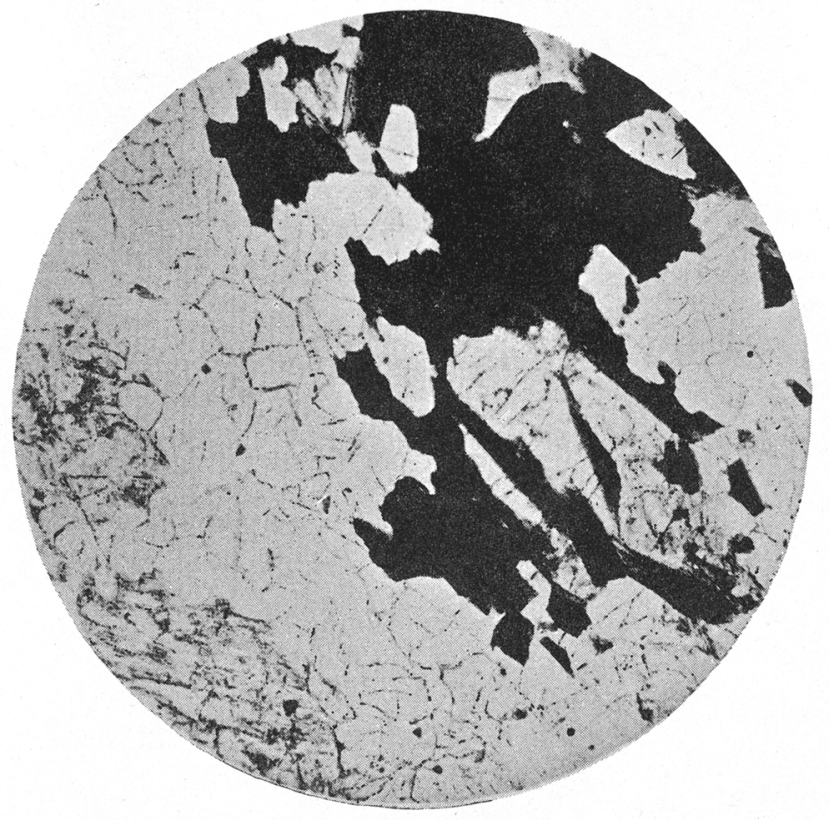

FIGURE 1-LITCHFIELDITE; NATURAL LIGHT.

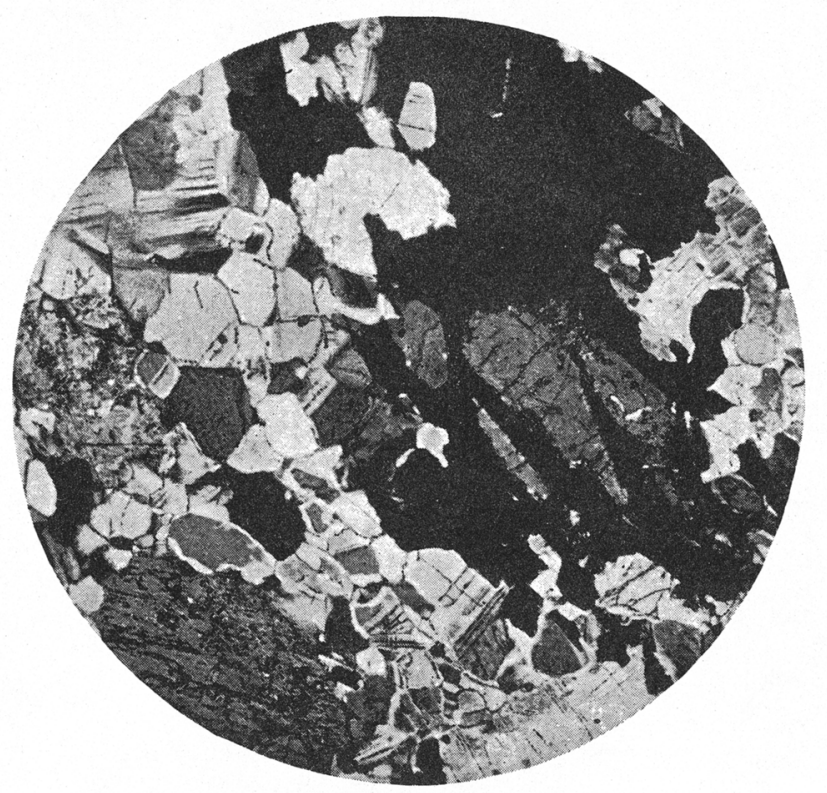

FIGURE 2-LITCHFIELDITE; CROSSED NICOLS.

MICROSTRUCTURE OF LITCHFIELDITE. 
